\title{
Hydrochemical and Isotopic Study of Groundwater in the North Djeffara Aquifer, Gulf of Gabès, Southern Tunisia
}

\author{
Mohamed Fethi Ben Hamouda ${ }^{1}$, Ahmed Mamou ${ }^{2}$, Jelloul Bejaoui ${ }^{1}$, Klaus Froehlich ${ }^{3}$ \\ ${ }^{1}$ UMTN, Isotope Hydrology and geochemistry Unit, CNSTN, 2020, Sidi Thabet, Tunisia \\ ${ }^{2}$ Observatoire du Sahel et du Sahara, Tunis, Tunisia \\ ${ }^{3}$ Viktor-Wittner-Gasse, Vienna, Austria \\ Email: F.benhamouda@enstn.rnrt.tn
}

Received July 23, 2013; revised August 25, 2013; accepted September 26, 2013

Copyright (C) 2013 Mohamed Fethi Ben Hamouda et al. This is an open access article distributed under the Creative Commons Attribution License, which permits unrestricted use, distribution, and reproduction in any medium, provided the original work is properly cited.

\begin{abstract}
The northern Djeffara aquifer system is located in the southeast of Tunisia and extends over an area of $400 \mathrm{~km}^{2}$. This multilayer system of aquifers is essentially recharged by infiltration of rain and by groundwater of the Continental Inter-calaire aquifer, and occurs mainly at two levels between 0 and $180 \mathrm{~m}$ depth that belong to the Mio-Pliocene to form the aquifers. A combined hydrogeologic and isotopic investigation using several chemical and isotopic tracers', i.e., major ions, $\delta^{18} \mathrm{O}, \delta^{2} \mathrm{H}$ and tritium, was carried out in order to determine the sources of water recharge to the aquifer and the origin of salinity. The results of geochemical and isotopic studies show that the groundwater in the south of the study area represents a mixture of the Djeffara aquifer groundwater and locally infiltrates modern recharge. In the northern part, the groundwater which resembles that of the Sekhira aquifer originates from locally infiltrated rain and runoff. The salinity of the groundwater is caused by dissolution of evaporate rocks (gypsum and halite minerals) in the aquifer system. The stable isotopes data do not support the hypothesis of mixing with seawater.
\end{abstract}

Keywords: Salinization; Hydrochemistry; Isotopes; Groundwater Recharge; Tunisia

\section{Introduction}

In many coastal hydrogeologic systems, the management of groundwater resources is constrained by the presence of brackish or saline waters that endangers, often irreversibly, the future of these resources [1]. While the source of salinity can sometimes be clearly identified to be modern seawater intrusion into aquifers, such a single source is not the case in many systems. Ancient marine intrusion, wind driven sea spray and marine aerosols deposited at the topsoil, effects of mobilised salts stored in the unsaturated zone, evaporative enrichment and local pollution may further contribute to the salinization of ground waters [2-4].

The Northern climatic aridity in southern Tunisia adversely affects agricultural and living conditions. Djeffara aquifer system is located in the south of Tunisia (Figure 1), in which the exploitation of the groundwater increased during the last decades. The increase of the water abstraction caused a decrease of the piezometric heads of the groundwater and changes in the recharge conditions as well as in the chemical composition of the groundwater. Highly mineralized water occurred in the more shallow part of the aquifer system. Recent droughts have also accentuated the natural hazard in this area. The increasing of the Djeffara aquifer exploitation has reduced artesian pressure in the area and caused the depletion of wells and springs. The main objective of this study is to integrate hydrogeological data with major ion geochemistry and isotopic signatures of ground waters in order to clarify the hydrodynamic functioning of the aquifer system and identify the major hydrochemical processes responsible for groundwater mineralization in order to demonstrate sustainable utilization of salt affected barren lands and saline groundwater to grow salt tolerant plants to provide a green cover, to improve environment and to obtain large amounts of biomass. The results of this study are presented in this paper.

The aquifer system in southeast Tunisia is an important water resource for the region and has been the subject of many studies [5-11].

\section{Climatic, Geological and Hydrogeological Setting}

The study area belongs to the Northern Djeffara aquifer 
system, which is located in the southeastern part of Tunisia about $35 \mathrm{~km}$ north of the town Gabès (Figure 2). It is

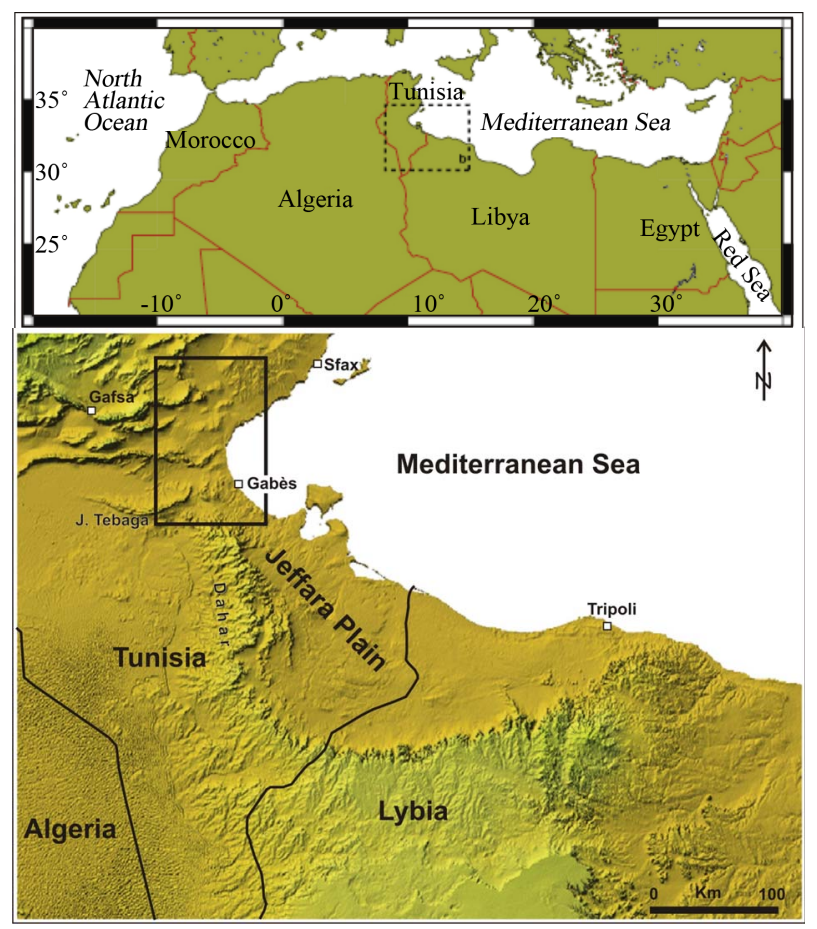

Figure 1. Location of the study area.

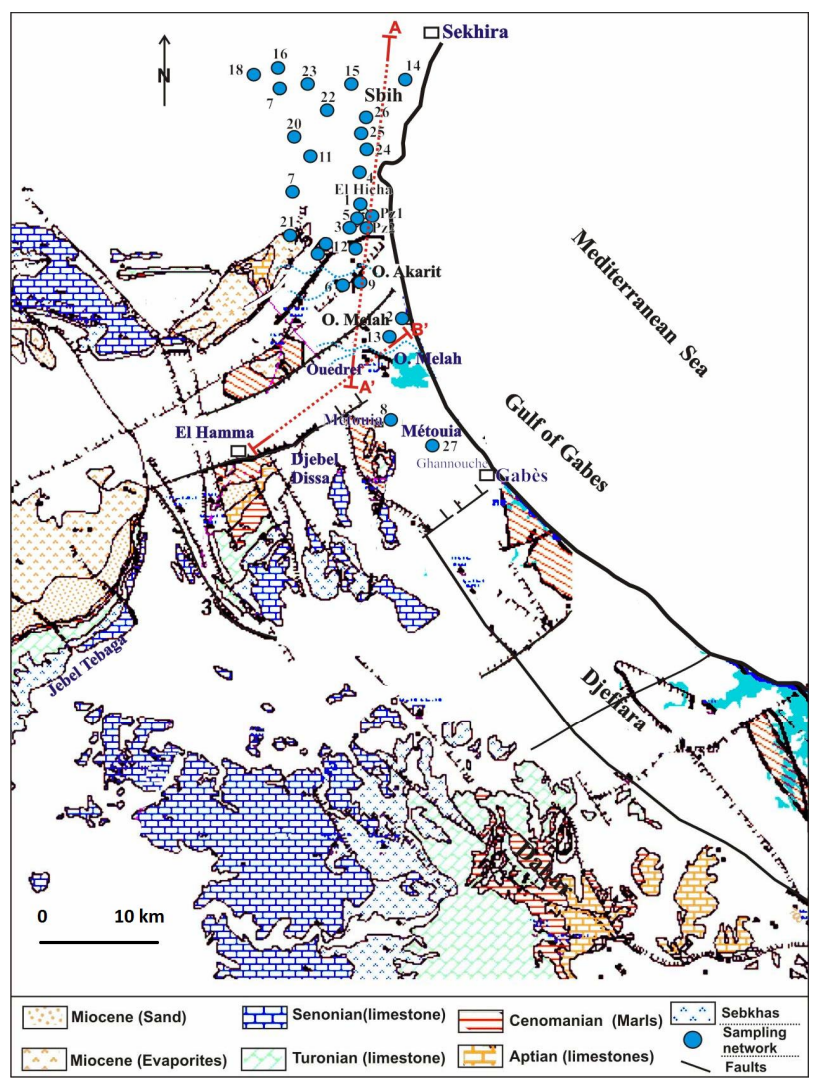

Figure 2. Geology and sampling network. bounded by the Gulf of Gabès in the east, El Hamma in the west, and the area of the town Sekhira in the north. The landscape is a coastal plain slightly sloping (3\%) towards the sea.

The climate of the region is semi-arid and of Mediterranean type with a dry and hot summer season and a wet and cool winter season. The long-term mean annual rainfall is at about $180 \mathrm{~mm}$ and the potential evaporation are $1300 \mathrm{~mm}$. The variability of the annual rainfall is rather high; years with rainfall higher than the long-term average were 1974, 1976, 1989, 1990 and 1996, whereas in 1982 and 1997 the rainfall was less than $60 \mathrm{~mm}$. There are no perennial rivers in this region; but intense storms occasionally cause surface runoff, which is discharged by wadis. Oued El Akarit is the major wadi. Gabes is a typical example of a semi-arid climate region where groundwater resources are intensively exploited for human needs as a result of agricultural and demographic development. The Djeffara aquifer system, it constitutes the main water resource in southeastern Tunisia. Intensive exploitation of the aquifer during last year's induced declining water levels, drying up of springs and increased risk to groundwater quality due to salinization.

In 2005 , the renewable water resources in the region were estimated to $19.5 \times 10^{6} \mathrm{~m}^{3} /$ year with annual exploitation in the order of $27.1 \times 10^{6} \mathrm{~m}^{3}$ (DGRE 2005).

The geological formations in the study area are composed by Cretaceous to Quaternary formations [8]. As shown in the lithostratigraphic column (Figure 3), the Cretaceous series are constituted mainly by hauterivianbarremian, Albian and Turonian stages. The Barremian, outcropping in the anticline at the south part of the study area, is formed by gypseous clay and anhydrite that has $200 \mathrm{~m}$ of thickness. It belongs to the Continental Intercalaire aquifer system. The Albian, which is a 20 to $40 \mathrm{~m}$ thick formation, is represented by a succession of dolomite, limestone and marl layers. The Turonian is composed of dolomite and crops out southeast of the study area. The Tertiary is represented by various series of Mio-Pliocene sediments composed of reddish gypseous clay and sand, which constitute the deep aquifer in the region. The Quaternary is formed by three terraces composed by red to yellow mud and clay with a crust of gypsum and sediment.

The coastal plain of Gabès is a succession of horsts and graben settings, represented by the anticlinal of the Tébaga in the west and the monoclinal of the Dahar in the south. Due to these two old anticlinal structures the permo-trassic substratum is brought up to very near the soil surface. Elsewhere, the layers are sloping in the direction of the Mediterranean and increase in thickness [12]. The groundwater of the Northern Djeffara multilayered aquifer system occurs mainly at four levels (Figure 4), a shallow aquifer consisting of Quaternary 


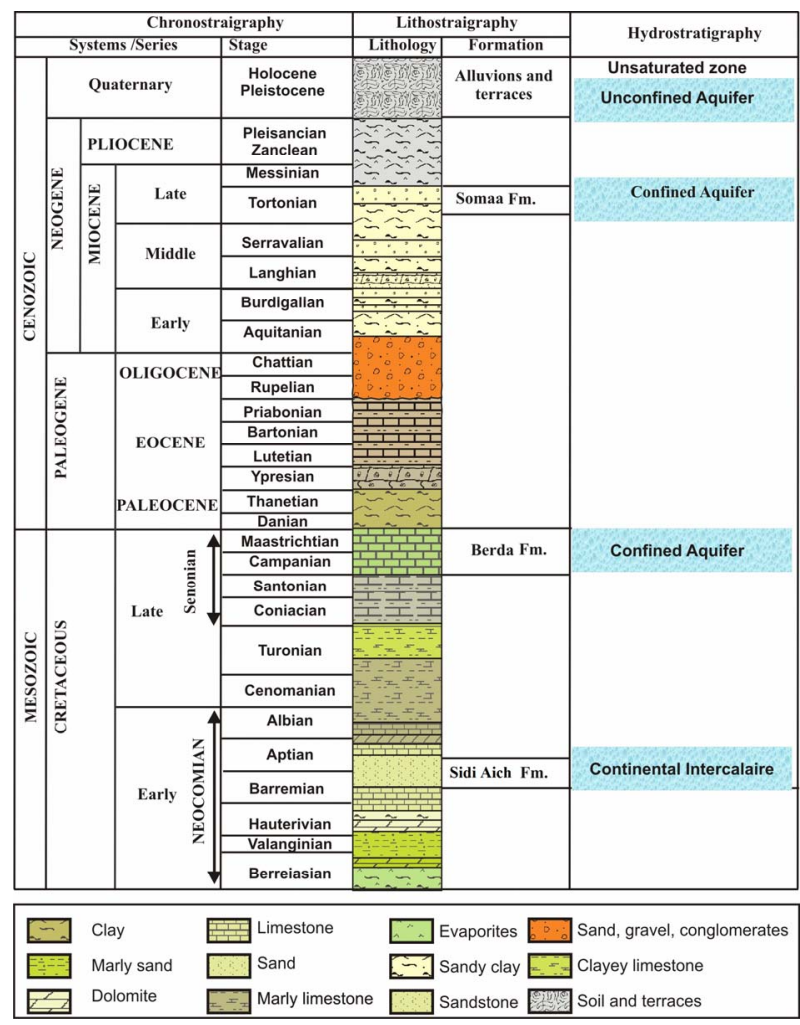

Figure 3. Hydrostratigraphic column of the study area.

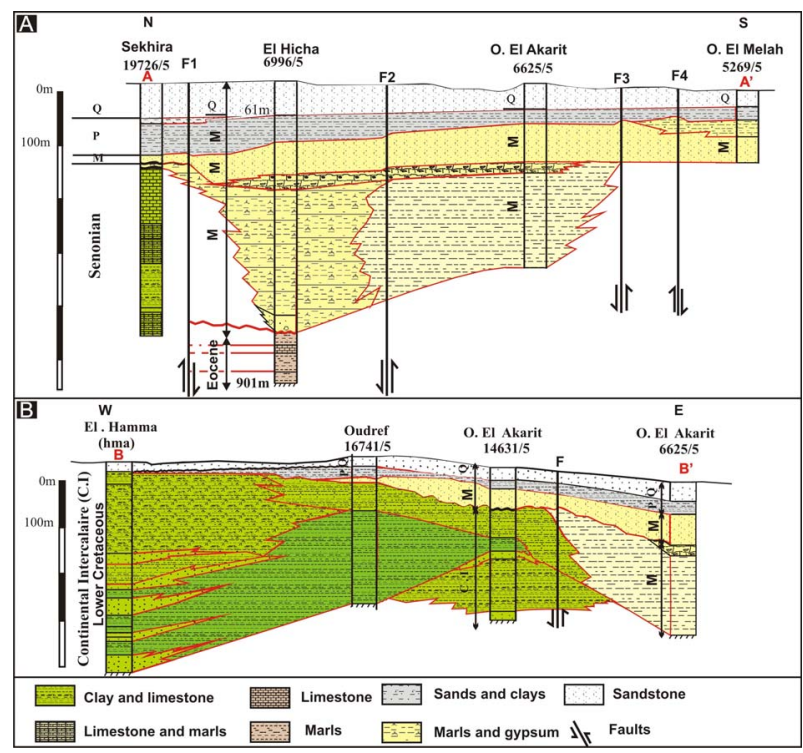

Figure 4. Lithostratigraphic correlation from South to North (A) and from East to West (B) through Oued El Akarit Basin.

alluviums up to depths of about $50 \mathrm{~m}$ and three deep aquifers between about 50 and $180 \mathrm{~m}$ : the upper Miocene intermediate aquifer, the Upper Cretaceous deep aquifer and the continental intercalaire.

The main aquifers levels are the deep aquifer formed by Cretaceous limestones (Senonian) and Miocene sands
(Pontien). Pontien sands spread under the coastal plain of Gabès in a zone where the post-cretaceous erosion intensified extensively the Senonian limestone karstification. These sands result from the overhaul of Barremian sandstone. Their thickness varies between 25 and $80 \mathrm{~m}$. It increases in direction to the sea and reaches a maximum in the two pits centred on Ghannouche and Oued El Melah [8]. These sands have a fine granulometry; their transmissivity ranges between $3 \times 10^{-3} \mathrm{~m}^{2} / \mathrm{s}$ and $35 \times$ $10^{-3} \mathrm{~m}^{2} / \mathrm{s}$, if an average thickness of $50 \mathrm{~m}$ is assumed. Values within this range were found in pumping tests carried out in boreholes capturing these sands (Métouia, El Hicha and Oudref) (Figure 4). More to the south these sands change laterally to the Senonian limestone that shelters the deep aquifer of the Djeffara. The transmissivity of the Senonian limestone ranges between $1 \times 10^{-3}$ and $35 \times 10^{-2} \mathrm{~m}^{2} / \mathrm{s}$. The karstification of this limestone results from the brittle tectonics that marked the region before it was buried under a Mio-Plio-Quaternary cover.

The shallow aquifer is replenished by rain and runoff. The main coastal sebkhas constitute its natural outlets (Figure 5).

The salinity of the shallow groundwater increased towards the coast. Regional hydrogeological studies $[9,10$, 13-16] suggest that the Miocene Pontien sand aquifer is in hydraulic communication with the Senonian limestone aquifers in the region of Gabès and with the Continental Intercalaire (Barremian sands) in the region of Ouedref. As for the shallow aquifer, the flow is in direction to the sea with a gradient of $2 \%$.

\section{Methodology and Analytical Data}

The study has been carried out in the framework of an interregional project (INT/5/144) financed by IAEA and was driven by practical questions related to use this water for growing salt tolerant plants. Previous chemical data come from work undertaken in 1972. For this study,

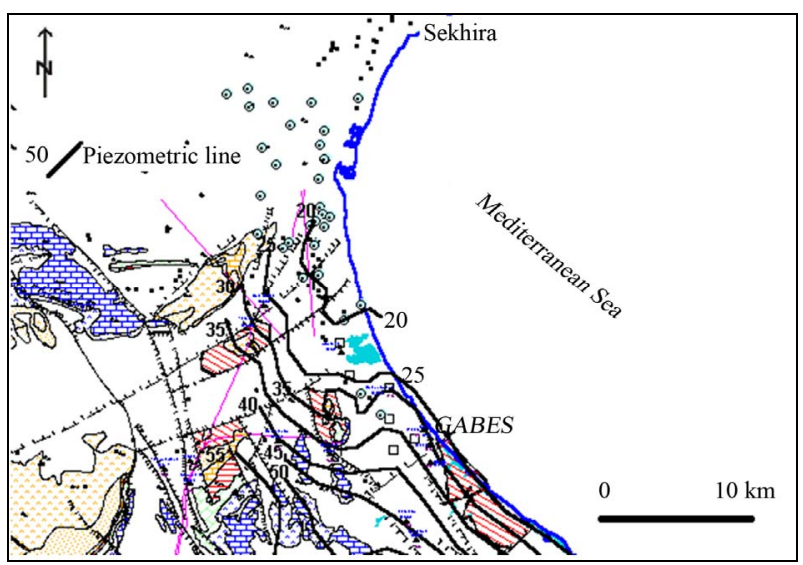

Figure 5. Piezometric contour map (in meters above mean sea level) of the study area. 
geographical position, depth to water table, electric conductivity and $\mathrm{pH}$ were measured in 29 sampling points in the study area (Figure 2) during field campaigns carried out from in 2002 (Table 1). Samples were also collected for measurement of major elements, stable isotopes $\left({ }^{2} \mathrm{H}\right.$, $\left.{ }^{18} \mathrm{O}\right)$ and tritium $\left({ }^{3} \mathrm{H}\right)$. Samples were taken after purging some piezometers. Boreholes and dug wells did not need to be purged because at the time of sampling water were extracted from these wells. The samples were taken from shallow aquifer (ShA) and Djeffara aquifer (JNG) (Table 1).

The chemical analyses of the water samples were performed at the Laboratory of Soil, Ministry of Agriculture, Tunis, and in the Radio Analyses and Environment

Table 1. Sampling sites of the study area in 2002 and average values of the chemical analyses (mg/l)

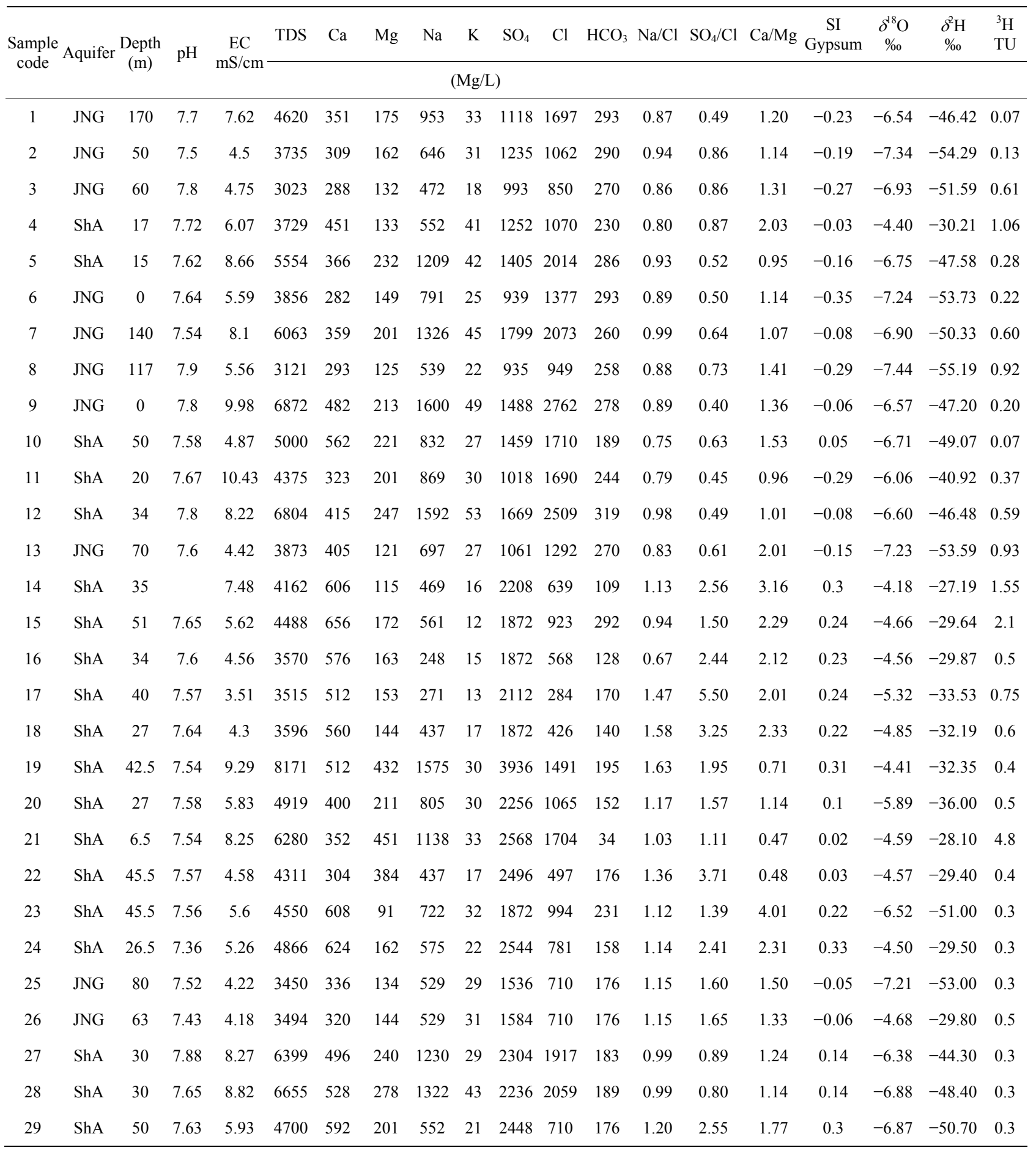


Laboratory, LRAE, Sfax. Major cations (Ca, Mg, Na, and $\mathrm{K}$ ) concentrations were analysed in filtered samples using an atomic absorption spectrometer with a furnace and anions $\left(\mathrm{Cl}, \mathrm{SO}_{4}\right.$ and $\left.\mathrm{NO}_{3}\right)$ concentrations were analysed in filtered samples using a Dionex DX 120 ion chromatograph equipped with an AG14 and an AS14 Ion Pac columns and an AS-40 auto-sampler. The charge balance between major anions and cations is better than $\pm 5 \%$.

Isotopes analysis of the water samples $\left({ }^{2} \mathrm{H}\right.$ and $\left.{ }^{18} \mathrm{O}\right)$ were performed by the Division of Radiation and Isotope Application, PINSTECH (Pakistan Institute of Nuclear Science and Technology) and supported by IAEA through INT project INT/5/144. Stable isotopes of oxygen and hydrogen were determined by isotope ratio mass spectrometry in a Finnigan MAT Gas Bench and analysed using continuous flow on a Finnigan MAT 252 mass spectrometer. The $\delta^{18} \mathrm{O}$ values in samples were analysed via equilibration with $\mathrm{CO}_{2}$ at $25^{\circ} \mathrm{C}$ for $24 \mathrm{~h}$ [17] and for the $\delta^{2} \mathrm{H}$ values via reaction with $\mathrm{Cr}$ at $850^{\circ} \mathrm{C}$ [18]. Both $\delta^{18} \mathrm{O}$ and $\delta^{2} \mathrm{H}$ values were determined relative to internal standards that were calibrated using IAEA SMOW standards. Data were normalised following Coplen [19] and are expressed relative to V-SMOW. Samples were measured at least in duplicates and the precision of the analytical measures is $\pm 0.1 \%$ for $\delta^{18} \mathrm{O}$ and $\pm 1 \%$ o for $\delta^{2} \mathrm{H}$. The results are reported as $\delta^{18} \mathrm{O}$ and $\delta^{2} \mathrm{H}$, where $\delta=\left(\left(R_{\text {sample }} / R_{\text {standard }}\right)-1\right) \times 1000$. Tritium $\left({ }^{3} \mathrm{H}\right)$ was measured by the IAEA at the Isotope Hydrology Laboratory, Vienna, Austria. Tritium content was measured by electrolytic enrichment and liquid scintillation spectrometry [20]. Tritium concentration is reported in Tritium Units (TU). One TU is defined as the isotope ratio ${ }^{3} \mathrm{H} /{ }^{1} \mathrm{H}=10^{-18}$.

\section{Results and Discussion}

\subsection{Chemical Characteristics}

The salinity of the groundwater is determined by the total dissolved solids (TDS) (Figure 6). The TDS content of groundwater samples ranges from 3121 to $8171 \mathrm{mg} / \mathrm{l}$ (the highest values are measured in the shallow aquifer).

It has been found that the chemical composition of the groundwater is not remarkably fluctuating during the different seasons (dry/wet). The chemical composition of groundwater plotted in a piper diagram (Figure 7) shows a trend of water classified under a $\mathrm{Na} \mathrm{Cl} \mathrm{SO}$ water type. The correlation diagrams of different major elements versus TDS values (Figures 8(a)-(d)) show that groundwater mineralization is mainly dominated by $\mathrm{Na}, \mathrm{Cl}$ and $\mathrm{Mg}$ contents for shallow levels and by $\mathrm{SO}_{4}, \mathrm{Cl}, \mathrm{Na}$, and $\mathrm{Ca}$ for the deep aquifer levels. The relationships between the major ions $\mathrm{Na}, \mathrm{K}, \mathrm{Ca}, \mathrm{Mg}, \mathrm{K}, \mathrm{SO}_{4}, \mathrm{HCO}_{3}$ and $\mathrm{Cl}$ are shown in (Figures 9(a)-(d)). In general, most ions are

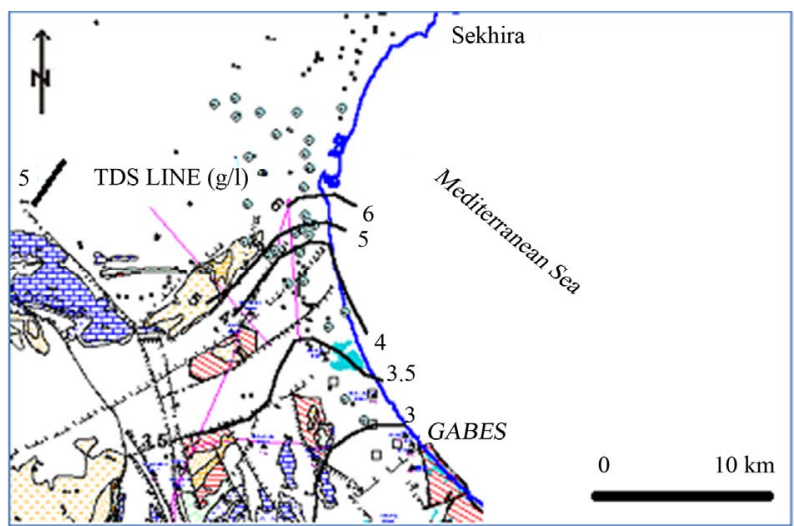

Figure 6. Groundwater salinity map measured as TDS (g/l) of El Djeffara Aquifer.

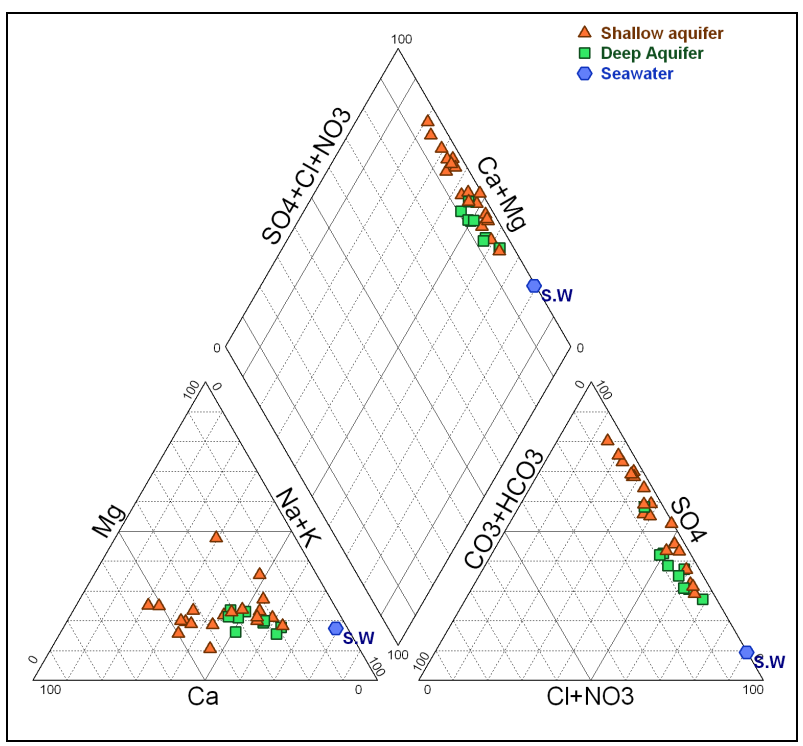

Figure 7. Piper diagram showing the composition of the Northern Djeffara groundwater in 2002.

positively correlated with $\mathrm{Cl}$, and especially $\mathrm{Na}, \mathrm{Mg}$, and $\mathrm{SO}_{4}$ show a strong correlation with $\mathrm{Cl}$, indicating that such ions are derived from the same source of saline waters. The positive correlation between $\mathrm{Na}$ and $\mathrm{Cl}$ (Figure 9(a)) contents $\left(\mathrm{R}^{2}=0.92\right)$, indicates the contribution of halite $(\mathrm{NaCl})$ dissolution to groundwater mineralization. It's also suggests that the predominance of sodium and chloride can be explained by the proximity of the sea, via the spray and/or a progress of seawater intrusion. Even for those taken far from the sea, the molar relationship $\mathrm{Na}^{+} / \mathrm{Cl}^{-}$does not differ very significantly from that of the Mediterranean (0.86) [21] and therefore is insufficient in distinguishing the origin of the water.

Any increase in this ratio above 1 would suggest some reaction of silicate minerals or cation exchange releasing $\mathrm{Na}$ at the expense of some other cation.

The processes of dissolution, precipitation and cationexchange are actively taking place within the ground- 


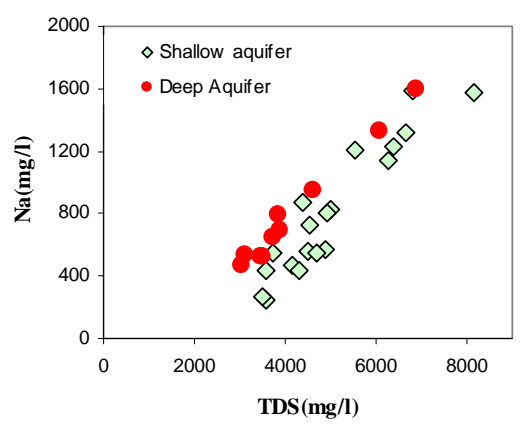

(a)

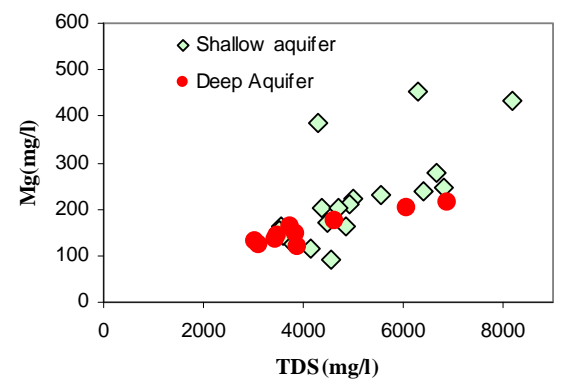

(c)

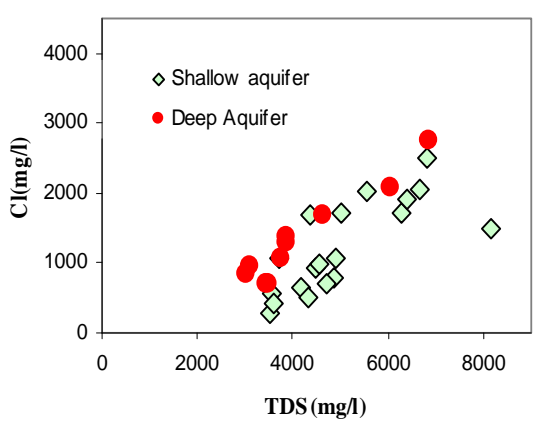

(b)

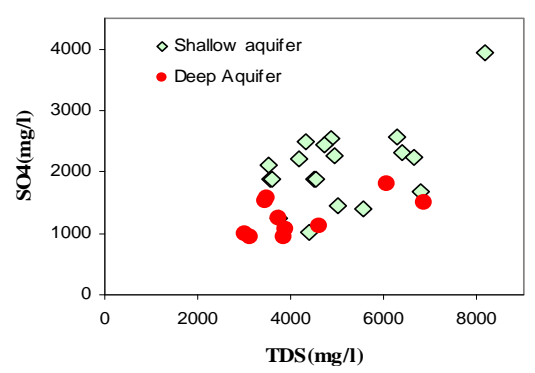

(d)

Figure 8. Correlation diagrams of different major elements versus TDS values (Figures 8(a)-(d)).

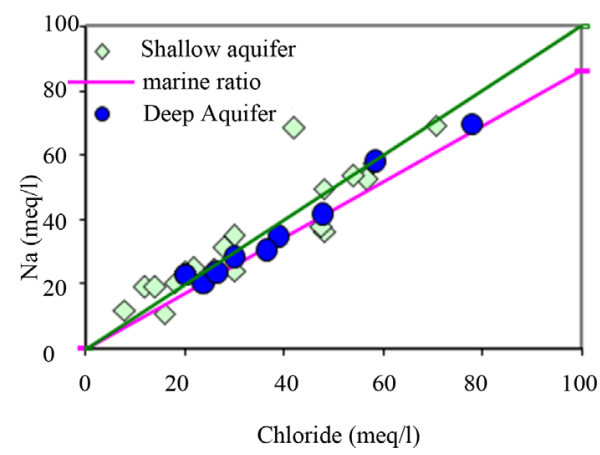

(a)

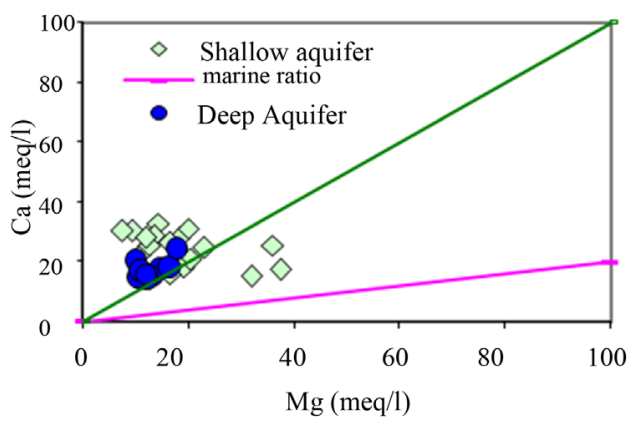

(c)

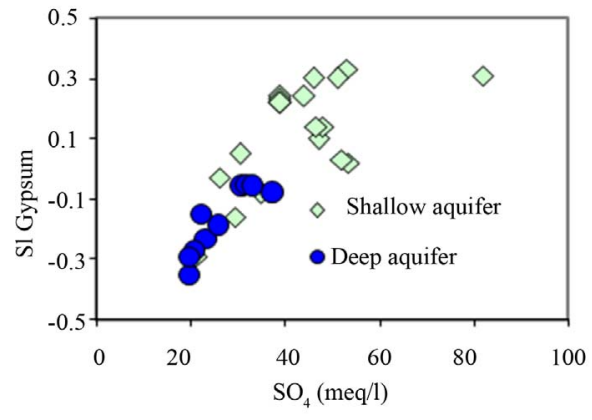

(b)

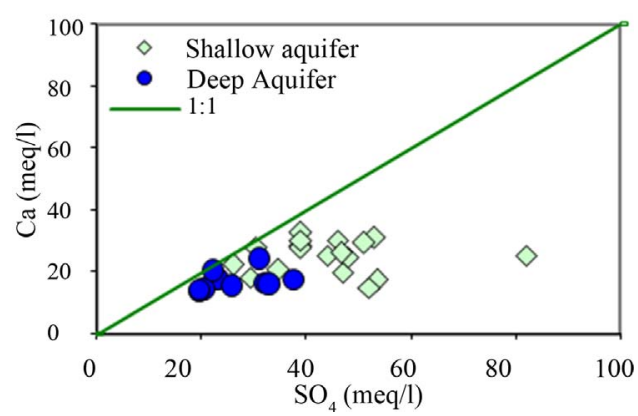

(d)

Figure 9. Relationships between the major ions $\mathrm{Na}, \mathrm{Ca}, \mathrm{Mg}, \mathrm{SO}_{4}$, and SI (Figures 9(a)-(d)).

water system. The results obtained indicate that the mineral phases of calcite, aragonite and dolomite are oversaturated in the groundwaters. However most of the groundwaters are unsaturated with respect to gypsum and anhydrite. It is postulated that mineral phases that are under saturated ( $\mathrm{SI} \leq 0.1)$ will tend to dissolve and mineral phases that are oversaturated $(\mathrm{SI} \geq 0.1)$ will precipitate these mineral phases out of solution. The computation of saturation indice (SI) by Wateq 4F program [22] shows a progressive saturation in gypsum with an in- 
crease in $\mathrm{SO}_{4}$ concentrations (Figure $\mathbf{9 ( b ) )}$ ).

The sampled groundwater are characterized by a great variability in $\mathrm{Ca}^{2+}$ and $\mathrm{Mg}^{2+}$ contents but most cases show a predominance of $\mathrm{Ca}^{2+}$ compared to $\mathrm{Mg}^{2+}$ (Figure 9(c)). The groundwater samples having a $\mathrm{Ca}^{2}+\mathrm{Mg}^{2+}$ ratio higher than 1 might indicate there is no mixture with sea water (marine ratio $=0.2$ ) [23]. The samples 5, $11,19,21$ and 22 are the only ones to have a $\mathrm{Ca}^{2}+/ \mathrm{Mg}^{2+}$ ratio less than 1 and the another source of $\mathrm{Ca}$ should be considered regarding water mineralization. Considering research area lithology, references are made to the existence of disperse layer of gypsum, which can be considered as "external" source of calcium to the system, and in this situation the relationship Ca-Mg will reflect this origin. Nevertheless, it is important not to exclude the formulated hypothesis of cation exchange within the aquifer system where clay and organic matter interact with water body, in order to explain the increase of sodium in the $\mathrm{Na}-\mathrm{Cl}$ relationship. In the $\mathrm{Ca}-\mathrm{Mg}$ relationship, the formulated ion exchange hypothesis should not be excluded, since it continues to be possible not only to explain the increase of sodium ( 2 sodium for 1 calcium) and simultaneously the decease of calcium in the groundwater composition will not be reflected in the $\mathrm{Ca}-\mathrm{Mg}$ relationship.

In the continuity of the above hypothesis (cation exchange) is coherent to the depletion in $\mathrm{Ca}^{2+}$ contents relative to $\mathrm{SO}_{4}{ }^{2-}$ in the sampled groundwaters, (Figure 9(d)), is probably due to cation exchange reactions ascribed to the clay fraction and possible existence of organic matter within the aquifer matrix as $\mathrm{Na}+$ is released and an depletion in calcium content can be observed. If one consider the gypsum lenses as another possible $\mathrm{Ca}^{2+}$ source for groundwater mineralization, $\mathrm{Ca}^{2+}$ could be removed by $\mathrm{Na}+$ exchange, but $\mathrm{SO}_{4}^{2-}$ content remains the "same". Therefore, ion exchange processes the dissolution of gypsum should be faced as important sources of groundwater salinity.
Pearson's correlation matrices [24] were used to find relationships between two or more variables directly related to salinity (EC, $\mathrm{Cl}^{-}, \mathrm{SO}_{4}^{2-}, \mathrm{Mg}^{2+}, \mathrm{Na}^{+}, \mathrm{K}^{+}, \mathrm{Ca}^{2+}$ ). Only correlations with $r>0.4$ are shown (Table 2). Samples showing $r>0.7$ are considered to be strongly correlated whereas $r>0.48$ to 0.7 shows moderate correlation. Strong correlations exist among the major elements, $\mathrm{Na}, \mathrm{Cl}, \mathrm{K}, \mathrm{Mg}$, and $\mathrm{EC} r>0.7$. These relationships clearly identify the main elements contributing to the groundwater salinity and their tendency to follow a similar trend (e.g. due to dissolution of evaporates or concentration by evaporation). Moderate correlations $(0.5<r<0.7)$ between $\mathrm{SO}_{4}$ and $\mathrm{Ca}$ with $\mathrm{EC}$ indicate that these ions tend to increase in concentration as the salinity of the water increases. The salinization of the groundwater would be expected to result from the ionic concentrations increasing due to both evaporation of recharge water and to the effects of interactions between the groundwater and the geological formations.

\subsection{Stable Isotopes Characteristics}

Define A separate study of ionic relationships and stable isotopes is not able to identify the origin of the water precisely. The combination of these two approaches is more explicit and in most cases even crucial. The stable isotopes, in combination with the chemical data, can be used for a more detailed characterization of the origin of the water and in particular the possible mixing of several components. Chemical and isotope tracers are essential tools for better understanding of groundwater origin ([25], [26]. The aquifer systems relevant to the Northern Jeffara of Gabes area have been subject to several isotope and geochemical studies, which include the shallow aquifer of Gabes and Skhira [27,28], the Jeffara aquifer [29,30], the Continental Intercalaire aquifer system $([9,29]$, and the Sfax aquifer [27].

Table 2. Pearson's correlation matrice.

\begin{tabular}{cccccccccc}
\hline Variables & $\mathrm{pH}$ & $\mathrm{c}^{\circ} 5^{\circ} \mathrm{C}$ & $\mathrm{HCO}_{3}^{-}$ & $\mathrm{Cl}^{-}$ & $\mathrm{SO}_{4}^{-}$ & $\mathrm{Ca}^{++}$ & $\mathrm{Mg}^{++}$ & $\mathrm{Na}^{+}$ & $\mathrm{K}^{+}$ \\
\hline $\mathrm{pH}$ & $\mathbf{1}$ & - & 0.484 & 0.411 & - & - & - & - & - \\
$\mathrm{c} 25^{\circ} \mathrm{C}$ & & $\mathbf{1}$ & - & $\mathbf{0 . 7 9 3}$ & - & - & $\mathbf{0 . 4 6 7}$ & $\mathbf{0 . 8 2 2}$ & $\mathbf{0 . 6 2 0}$ \\
$\mathrm{HCO}_{3}^{-}$ & & & $\mathbf{1}$ & 0.418 & - & - & - & - & - \\
$\mathrm{Cl}^{-}$ & & & & $\mathbf{1}$ & - & - & - & $\mathbf{0 . 9 2 3}$ & $\mathbf{0 . 8 3 7}$ \\
$\mathrm{SO}_{4}^{-}$ & & & & $\mathbf{1}$ & $\mathbf{0 . 4 7 9}$ & $\mathbf{0 . 6 4 7}$ & - & - \\
$\mathrm{Ca}^{-}$ & & & & & $\mathbf{1}$ & - & - & - \\
$\mathrm{Mg}+$ & & & & & & 1 & $\mathbf{0 . 5 3 8}$ & - \\
$\mathrm{Na}+$ & & & & & & & 1 & $\mathbf{0 . 8 0 3}$ \\
$\mathrm{K}+$ & & & & & & & & 1 \\
\hline
\end{tabular}


The measured isotopic composition of the groundwater in the study area is compiled in Table 1. Under the climatic condition prevailing in the study area, recharge only takes place when rainfall is sufficiently high. The weighted (by rain amount) annual average of the stable isotope composition in rain has been considered as a good estimate for modern recharge [30]. The calculated values are: $(-4.59 \pm 0.8) \%$ for $\delta^{18} \mathrm{O},(-26.7 \pm 9.0) \%$ for $\delta^{2} \mathrm{H}$, and $(10 \pm 4) \%$ for the deuterium excess (d-exc $=$ $\left.\delta^{2} \mathrm{H}-8 \cdot \delta^{18} \mathrm{O}\right)$.

The Deuterium-Oxygen 18 diagram (Figure 10) shows two group of water.These two sources of the groundwater can also be seen in the $\delta^{18} \mathrm{O}$-depth plot (Figure 11). There are two clusters of data, the first around $-7 \%$ in $\delta^{18} \mathrm{O}$ represents mainly deep groundwater in the south of the study area, while the group around $-4.5 \%$ represents groundwater from near to surface to about $50 \mathrm{~m}$ depth in the northern part of the study area. Additional evidence for these conclusions is provided by the spatial distribution of the $\delta^{18} \mathrm{O}$ values, which shows

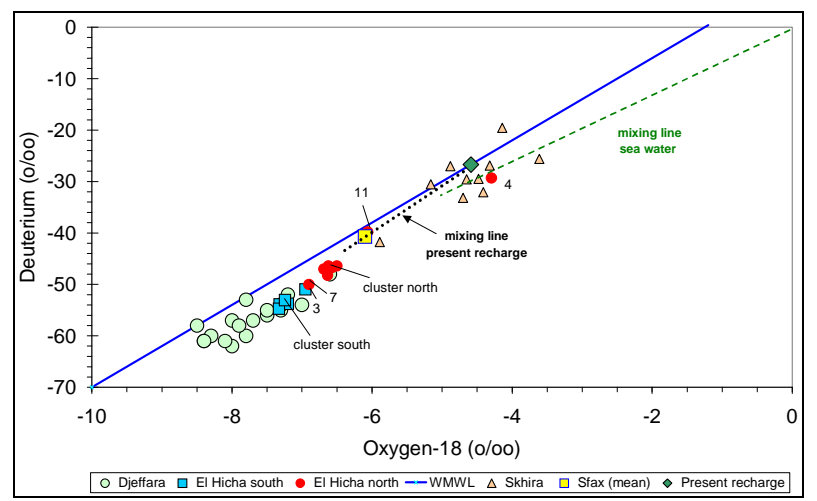

Figure 10. Isotopic content $\left({ }^{18} \mathrm{O},{ }^{2} \mathrm{H}\right)$ in groundwater from El Hicha and other neighbouring aquifers. The data of the Djeffara aquifer have been taken from Aranyossy and Mamou (1985) and the data of the Sfax and Skhira aquifers are from A. Maliki, 2000.

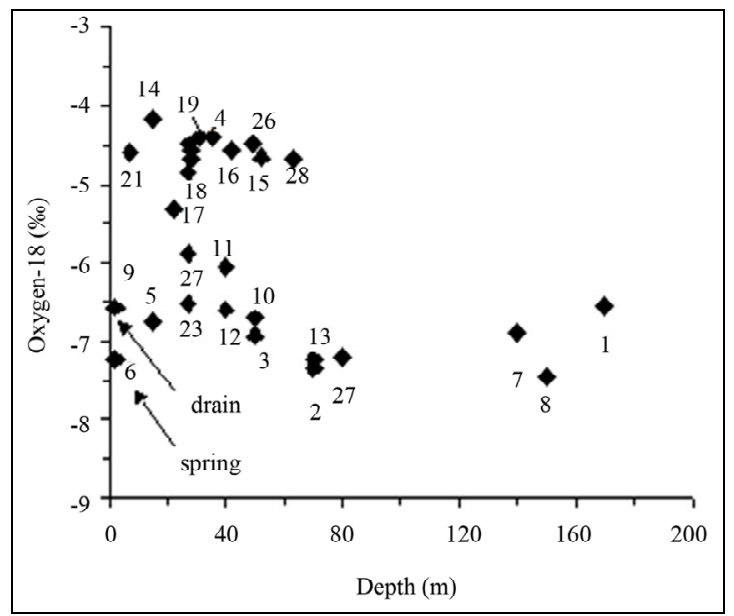

Figure 11. The $\delta^{18} \mathrm{O}-$ depth plot. that the lower $\delta^{18} \mathrm{O}$ values are spread over the southern part of the study area, while the higher values are concentrated in the northern part. Eventually, the comparison of the isotopic composition of the study area groundwater with the one of neighbouring regional aquifers (Djeffara in the south of gabès city, Sfax and Skhira in the north) provides a salient explanation of the groundwater origin (Figure 10). The southern group of the El Hicha groundwater appears to be Djeffara groundwater mixedwith varying proportions of modern local recharge. Assuming that sample 8 represents deep Djeffara groundwater, it has been estimated that the proportion of modern recharge in the groundwater of this group can reach up to $50 \%$ (sample 11). At site 17 the groundwater represents either $100 \%$ locally infiltrated water slightly enriched in stable isotopes through partial evaporation during infiltration, or a mixture of about $70 \%$ modern recharge and 30\% Djeffara groundwater.

The cluster at higher $\delta^{18} \mathrm{O}$ values represents modern recharge isotopically modified by varying degree of evaporation during rain or runoff infiltration. This groundwater occurs mainly in the north and is isotopically nearly identical with Skhira groundwater.

Furthermore, one possible explanation for the enrichment detected in the other points that present "heavy isotopic content" and smaller mineralization, this situation punctually can be explained by groundwater evaporation in the borehole or during the sample collection.

\subsection{Tritium}

Tritium concentration in precipitation is recorded at the GNIP (Global Network of Isotopes in Precipitation) stations, Tunis about $300 \mathrm{~km}$ to the north (data available 1968-1997), and Sfax station, approximately $90 \mathrm{~km}$ to the northeast of the study area and at practically the same altitude (data available 1992-2003). Tritium is known as an indicator of recent groundwater recharge. In the study area, a few samples have tritium values significantly higher than the detection limit of about 0.3TU (Table 1, Figure 12) and appear to represent bomb-tritium infiltrated in the groundwater after the end of the 1950s or beginning of $1960 \mathrm{~s}$. Modern recharge at these sites is also indicated by the measured $\delta^{18} \mathrm{O}$ values, which are around $-4.5 \%$ (estimated for modern recharge). The higher $\delta^{18} \mathrm{O}$ value of site 10 (dug well, not included in Table 1) is due to evaporation as indicated by its deuterium excess, which was found to be $8 \%$ lower than in most other cases (Figure 12).

Using the exponential model [31], the mean residence time (MRT) of the groundwater can be estimated by the measured tritium values. The results show that groundwater with 1 to $5 \mathrm{TU}$ during the investigation period, has a MRT between 100 and 30 years (Figure 12, inset). The 


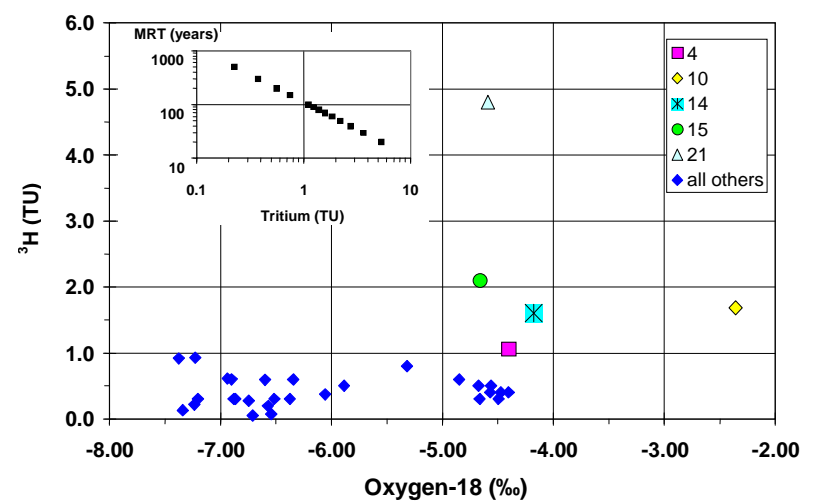

Figure 12. Tritium versus $\delta^{18} \mathrm{O}$. The inset shows the MRT of the groundwater, which has been calculated from the tritium values assuming on exponential residence time distribution function.

tritium values above the detection limit found in deeper groundwater (Figure 12), point to admixture of shallow groundwater.

\section{Sumary and Conclusions}

On the basis of the evaluation of combined isotope and chemical data the following can be concluded.

Groundwater in the south of the El Hicha study area originates mainly from the Djeffara aquifer. Djeffara groundwater is known to be formed by discharge of the Continental Intercalaire in the fault system of the El Hamma region. Often the groundwater of this group contains certain proportions of locally replenished shallow groundwater. The proportion of this modern recharge reaches values up to more than $50 \%$.

In the northern part the groundwater is mainly formed by infiltrating rain and runoff. The isotope data indicate that in several cases the infiltrating water is subject to partial evaporation, which is typical for semi-arid conditions prevailing in the study area.

In the southern part of the study area the contribution of Djeffara groundwater is dominating whereas in the northern part a remarkable proportion of modern recharge originating from infiltration of rain and runoff (in wadis) is indicated by the isotopic composition of the groundwater samples. Therefore, groundwater in the southern part of the study area appears to be less vulnerable to overexploitation and pollution.

The salinity of the groundwater is caused by dissolution of minerals/evaporites deposited in the aquifer system. The higher values of the dissolved anions and cations in the northern part of the El Hicha area are due to higher sodium and chloride concentrations. The changes of the latter concentration seem to be associated with changes of the proportion of local recharge. So far, there are no indications of seawater infiltrations.

\section{Acknowledgements}

This work greatly benefited from financial and logistical support provided by several organizations to which we address our thanks: International Atomic Energy Agency, Vienna, Austria; PINSTECH, Pakistan; Ministry of Agriculture: CRDA de Gabès, Direction des Sols; Institut National de Genie Rural Eaux et Forets; Ecole Nationale des Ingénieurs de Sfax; and the Centre National des Sciences et Technologies Nucléaires, Tunisia. These initiatives have been supported by a technical cooperation project of the International Atomic Energy Agency (IAEA), Vienna.

\section{REFERENCES}

[1] J. W. Lloyd, K. W. F. Howard, N. R. Pacey and J. H. Tellam, "The Value of Iodine as Parameter in the Chemical Characterization of Groundwaters," Journal of Hydrology, Vol. 57, No. 3-4, 1982, pp. 247-265. http://dx.doi.org/10.1016/0022-1694(82)90149-4

[2] C. A. J. Appelo and D. Postma "Geochemistry, Groundwater and Pollution" Vol. 536, Balkema, Rotterdam, 1993.

[3] I. Cartwright, T. R Weaver, S Fulton, C. Nichol, M. Reid and $\mathrm{X}$. Cheng, "Hydrogeochemical and Isotopic Constraints on the Origins of Dryland Salinity, Murray Basin, Victoria, Australia," Applied Geochemistry, Vol. 19, No. 8, 2004, pp. 1233-1254. http://dx.doi.org/10.1016/j.apgeochem.2003.12.006

[4] P. D. Glynn and L. N. Plummer, "Geochemistry and the Understanding of Groundwater Systems," Hydrogeology Journal, Vol. 13, No. 1, 2005, pp. 263-287. http://dx.doi.org/10.1007/s10040-004-0429-y

[5] ERES, "Etude des Ressources en eau du Sahara Septentrional, Algérie, Tunisie," Rapport sur les résultats du projet conclusions et recommandations, Vol. 44, UNESCO, Paris, 1972.

[6] R. Gonfiantini, G. Conrad, J. Ch. Fontes, G. Sauzy and B. R. Payne, "Isotopic Investigation of the Continental Intercalaire Aquifer and Its Relation to Other Aquifers in Northern Sahara," Isotope Techniques in Groundwater Hydrology, Proceedings Series, Vienna, 1974, pp. $227-$ 241.

[7] J. C. Fontes, R. Coque, L. Dever, A. Filly and A. Mamou, "Paléohydrologie Isotopique de l'oued el Akarit (sud Tunisie) au Pleistocène Supérieur et à l'holocène (Paleohydrology Isotopic Wadi el Akarit (southern Tunisia) Upper Pleistocene and Holocene," Palaeogeography, Palaeoclimatology, Palaeoecology, Vol. 43, No. 1-2, 1983, pp 4-62. http://dx.doi.org/10.1016/0031-0182(83)90047-0

[8] A. Mamou, "Caractéristiques et évaluation des ressources en eau du sud tunisien," Thèse de Doctorat d'Etat Es Sciences à l'Univ Paris-Sud (Characteristics and Evaluation of water Resources in Southern Tunisia)," PhD State Es Sciences, University of South-Paris, 1990, 425 p.

[9] W. M. Edmunds, P. Shand, A. H. Guendouz, A. S. Moulla, A. Mamou and K. Zouari, "Recharge Characteristics 
and Groundwater Quality of the Grand Erg Oriental Basin," British Geological Survey, Wallingford, Final report, 1997, 9 p.

[10] W. M. Edmunds, A. Guendouz, A. Mamou, A. Moulla, P. Shand and K. Zouari, "Groundwater Evolution in the Continental Intercalaire Aquifer of Southern Algeria and Tunisia: Trace Element and Isotopic Indicators," Applied Geochemistry, Vol. 18, No. 6, 2003, pp. 805-822. http://dx.doi.org/10.1016/S0883-2927(02)00189-0

[11] A. Guendouz, A. S. Moulla, W. M. Edmunds, K. Zouari, P. Shand and A. Mamou, "Hydrogeochemical and Isotopic Evolution of Water in the Complexe Terminal Aquifer in the Agerian Sahara," Hydrogeology Journal, Vol. 11, No. 4, 2003, pp. 483-495. http://dx.doi.org/10.1007/s10040-003-0263-7

[12] A. F. Mekrazi, “Contribution à l'étude Hydrogéologique de la Région de Gabès-Nord Thèse de 3ème Cycle Présentée à l'Univ de Bordeaux I," Contribution to the hydrogeological Study of the Gabès Region North 3rd Cycle Thesis, University of Bordeaux I, 1975.

[13] R. Rouatbi, “Contribution à l'étude hydrogéologique du Karst enterré de Gabès Sud Tunis, BIRH, (Contribution to the Study of Hydrogeological Buried Karst of South Gabes)," PhD Thesis, University of Montpellier, 1967, $235 \mathrm{p}$.

[14] R. Trabelsi, M. Zairi and H. Ben Dhia, "Groundwater Salinization of the Sfax Superficial Aquifer, Tunisia," $\mathrm{Hy}$ drogeology Journal, Vol. 15, No. 7, 2007, pp. 1341-1355. http://dx.doi.org/10.1007/s10040-007-0182-0

[15] R. Trabelsi, A. Kacem, K. Zouari and K. Rozanski "Quantifying Regional Groundwater Flow between Continental Intercalaire and Djeffara Aquifers in Southern Tunisia Using Isotope Methods," Environmental Geology, Vol. 58, No. 1, 2009, pp. 171-183. http://dx.doi.org/10.1007/s00254-008-1503-x

[16] J. Makni, F. Ben Brahim, S. Hassine, S. Bouri and H. Ben Dhia "Hydrogeological and Mixing Process of Waters in Deep Aquifers in Arid Regions: South East Tunisia," Arabian Journal of Geosciences, 2013. http://dx.doi.org/10.1007/s12517-012-0793-1

[17] S. Epstein and T. K. Mayeda, "Variations of ${ }^{18} \mathrm{O}$ Content of Waters from Natural Sources," Geochimica et Cosmochimica Acta, Vol. 4, No. 5, 1953, pp. 213-224. http://dx.doi.org/10.1016/0016-7037(53)90051-9

[18] M. L. Coleman, T. J. Shepherd, J. J. Durham, J. E. Rouse and G. R. Moore, "Reduction of Water with Zinc for Hydrogen Isotope Analysis," Analytical Chemistry, Vol. 54, No. 6, 1982, pp. 993-995. http://dx.doi.org/10.1021/ac00243a035

[19] T. B Coplen, "Normalization of Oxygen and Hydrogen Isotope Data," Chemical Geology, Vol. 72, No. 4, 1988, pp. 293-297.

[20] C. B. Taylor and P. Schwarz, "Deionization Procedure for Large Quantities of Tritium-Free Water Using an Ion-Exchange Column," The International Journal of Applied Radiation and Isotopes, Vol. 28, No. 6, 1977, pp. 605605. http://dx.doi.org/10.1016/0020-708X(77)90047-3
[21] B. F. Jones, A. Vengosh, E. Rosenthal and Y. Yechieli, "Geochemical Investigations," In: J. Bear, et al. Eds., Seawater Intrusion in Coastal Aquifers-Concepts, Methods and Practices, Kluwer Academic Publishers, Dordrecht, 1999, pp. 51-72.

http://dx.doi.org/10.1007/978-94-017-2969-7 3

[22] L. N. Plummer, B. F. Jones and A. H. Truesdell, "WATEQF, a Fortan IV version of WATEQ, a Computer Program for Calculating Chemical Equilibrium of Natural Waters," US Geological Survey, Water Resources Research, 1976.

[23] A. Vengosh and A. Ben-Zvi, "Formation of a salt plume in the Coastal Plain Aquifer of Israel: the Be'er Toviyya region," Journal of Hydrology, Vol. 160, No. 1-4, 1994, pp. 21-52. http://dx.doi.org/10.1016/0022-1694(94)90032-9

[24] A. R. H. Swan and M. Sandilands, "Introduction to Geological Data Analysis," Blackwell, Oxford, 1995.

[25] C. I. Voss and W. Wood, "Synthesis of Geochemical, Isotopic and Groundwater Modeling Analysis to Explain Regional Flow in a Coastal Aquifer of Southern Oahu, Hawaii," Mathematical Models and Their Applications to Isotope Studies in Groundwater Hydrology: Proceeding of a Final Research Co-Ordination Meeting, IAEA, Vienna, 1994, pp. 147-178.

[26] T. Vitvar, P. K. Aggarwal and J. J. McDonnell, "A Review of Isotope Applications in Catchment Hydrology," In: P. K. Aggarwal, J. Gat and K. F. O. Froehlich Eds., Isotopes in the Water Cycle: Past, Present and Future of a Developing Science, 2005, pp. 151-170.

[27] M. Maliki, "Etude Hydrogéologique, Géochimique et Isotopique des Eaux de la Nappe Profonde de Sfax, Thèse de 3ème Cycle de la Faculté de Sciences de Tunis," (Hydrogeological Study, Geochemical and isotopic waters of the deep groundwater Sfax), Thesis Faculty of Sciences of Tunis, 2000.

[28] H. Celle-Jeanton, K. Zouari, Y. Travi and A. Daoud, "Isotopic Characterisation of the Precipitation in Tunisia. Variations of the Stable Isotope Compositions of Rainfall Events Related to the Origin of Air Masses," Earth and Planetary Science Letters, Vol. 333, 2001, pp. 625-631.

[29] J. F. Aranyossy and A. Mamou, "Contribution of Nuclear Techniques in the Study of Aquifers South Tunisia," Project Report, RAF/8/007 IAEA, Vienna, 1985.

[30] M. F. Ben Hamouda, H. Ben Kraiem, A. Mahjoub, B. Labidi, R. Ghoudi, H. Hamrouni, H. Nasr, K Zouari, K. Froehlich, M. I. Sajjad and E. Garcia-Agudo, "Geochemical and Isotopic Characterization of Groundwater Resources in El Hicha Region, Gabes, Southern Tunisia" Proceeding of the International Conference on the Study of Environmental Change Using Isotope Techniques, Vienna, 2001, pp. 457-459.

[31] A. Zuber, "Mathematical Models for the Interpretation of Environmental Radioisotopes in Groundwater Systems," In: B. P. Fritz and Fontes, J.C., Eds., Handbook of Environmental Isotope Geochemistry, 1st Edition, Vol. II. The Terrestrial Environment, Elsevier Science Publishers, New York, 1986, pp. 1-59. 